\title{
ОТ ПСИХОЛОГИИ СМЫСЛА К СМЫСЛУ ПСИХОЛОГИИ. ЭКЗИСТЕНЦИАЛЬНЫЕ АРХЕТИПЫ
}

\begin{abstract}
Аннотация. По ту сторону натурализма не существует залогов того, что часто упоминаемые экзистенции извечны и исходят из единого сознания, наделены единым смыслом и погружены в унифицированный процесс мышления. Аргументом в пользу такого утверждения выступает общность языка; но семантические структуры так сложно устроены не в ориентации на "отражение мира», но в видах коммуникации онтологически различных экзистенций и их продуктивного связывания. Тип экзистенции конституирован осмыслением, и неизбежно направлен на выявление метафизики (трансиендентности) предметной сферы; но в рамках базальных экзистенций варьируются мотив и ракурс осмысляемого. Уже эта схематическая экспозиция позволяет говорить о типологии смыслов экзистенции и намечать их онтологические различия - вместе с тем удерживая вопрос о смысле их связи, очевидно, не предшествующем реальной общности (общине), но вместе с нею возникшем и в ней непосредственно воплощённом. Назовем базальные архетипы, “вытесняемые» в сферу бессознательного не в силу их чужеродности сознанию, но по причинам их онтологической диспозиции в составе психического, роли "призм", предсознательных установок, привносящих в миро-окружность "смысл", не сводимый к наличным формам и априори выступающий субъектом их внятности: архетип Всевышнего, Бога-Отиа, Абсолюта, Единого и пр.; архетип Власти; архетип Капитала; архетип Сервера.

Ключевые слова: психология смысла, смысл психологии, архетипы, экзистенции, экзистенциалы, базальные архетипы, Абсолют и Единое., власть, капитал, сервер.
\end{abstract}

\section{Предисловие}

За последнее столетие онтология и психология заметно сблизились. Конец классической философии обозначил себя смещением её устоев «по направлению к дольнему»; размечая «внутреннее», она, утратив веру в самобытность трансцендентного, предуготовляла ему место в психике, крестясь на портрет И. Канта. В рядах психологов рождался встречный энтузиазм; но всякий при этом питался собственными иллюзиями. Философы грезили о позитиве и твердой почве фактов. Авангард психологии уже перекроил норму в частный случай болезни; хотелось чего-то большего. Антропный призрак манил перспективами. Отталкиваясь от фактов сознания, сознание нащупывало почву их осмысления. «Между сознанием и реальностью поистине зияет пропасть смысла»ㄹ. Э. Гуссерль счи-

\footnotetext{
1 Гуссерль Э. Идеи к чистой феноменологии и феноменологической философии (1913). М.: Лабиринт, 1994. С. 11.
}

тает явления сознания «уже не «объектами», но «единицами смысла»»². И М. Хайдеггером продолжается углубление в его онтологию: «Осмыслением подразумевается больше, чем просто осознание чего-либо. Мы еще далеки от осмысления, пока просто что-то сознаем. Осмысление требует большего. Оно - отданность достойному вопрошания» ${ }^{3}$. Опорные точки начинали проступать «единицами смысла» в перекодировке осознанной реальности, обретении ею места и роли в составе бытия (между тем в априоризме фундаментальной значимости осознания явственно ощутим привкус метафизики); «симптом» очерчивал стыки экзистенции и реальности («абсурда» и упорядоченного).

Но феноменология как строгая наука не слишком сочеталась с экзистенциальной почвой: практики экзистенциальной психологии и психо-

\footnotetext{
Там же. С. 14.
}

Хайдеггер М. Время и бытие: статьи и выступления. М.: Республика, 1993. С. 251. 


\section{Философия и психология}

терапии лишь усиливали мировоззренческий и психологический кризис, ту бурю, которая изнутри разрывала методы оперативной фиксации и абсурд непрестанного выхода существования из своих пределов. Вместе с тем отстранённое внимание выявляло и истоки их общности, обусловленность методом (интроспекции); и «факты сознания», и психология экзистенциального толка обретали опоры в робинзонадах, утративших связь с историей и замкнутых в скорлупу феноменальных констатаций. Робинзонады оторваны от социальной почвы, претендующей и на фактическую обоснованность, но не игнорирующей производность внутреннего от трудноуловимых на пути интроспекции факторов: ценностей и пропагандистских траншей (с «программированием» подсознания). Их безусловный катехизис включает классический постулат всеобщности сознания, единства его (истинной) устроенности; между монизмом философской установки и эмпирикой диагностики открывалась лакуна, путь через которую мостился «экзистенциалами».

Между тем поиск единого для бушмена и халдея механизма сознания, характерного для «человека», напоминает спиритический сеанс вызывания классических духов. Сомнительно и убеждение в том, что брахману в процессе медитации является Брахман в славе, величии и всех инсигниях; но интроспекция зиждется на подобном натурализме, спиритическом сеансе вызова духов вселенских законов (в отличие от брахмана, приверженцу современной философии в его внутреннем предстает истинно-всеобщее, поскольку сам он рассматривает себя в качестве лишь инструмента, механизма безличной «фиксации»; трогательное уничижение).

Изгнание бесов метафизики из внешнего мира переселяет их в мир внутренний; на время закрепившись на плацдарме сознания, они с боями отступают вглубь территории, в заповедную зону «смысла», где и занимают глухую оборону.

На пути отступления змей познания время от времени сбрасывает старую кожу, оставляя метки на отданной территории; эти метафизические зарубки остаются в ткани наступающего позитивного сознания, представляясь, например, «человеком», как из глубин вышедшим и от века предуготовленным родовым единством - очевидно, натуральной выделки (логика при этом приносится в жертву политкорректности, совершая над собой подлинное насилие; но если всё же не считать человека производным от биологической приро- ды, определяя в качестве homo sapiens sapiens, и его родовое единство следует утвердить в устроении разума; попыток такого рода было предпринято предостаточно).

Коррекция необходима как в отношении устоев психики до и вне идеологий (или с ними в синкретичном единстве), так и в отношении феноменологии причин, фактам придавшим смысл (в опоре на ретроспекции мотивов), установившим экзистенции опорными пунктами бытия.

Первое очерчивает несколько абсурдную «чистую психику человека», бессознательное в форме предтечи сознания. Философию абсурда следует эксплицировать в психологических ее феноменах, экзистенции позитивно обосновав (в отечественной науке этим путем продвигались Ю.М. Бородай, Ф. Гиренок и пр.). Предмет психологии следует прежде очистить от шелухи и наслоений сознательного, не достигая слоев зоологического, с тем, чтобы рассмотреть почву «человеческого, слишком человеческого» в ее экстазах и псевдо-животной явственности. При подобном анатомировании можно рассчитывать на встречу с ювенальным смыслом, сознания не подразумевающим.

Второе предполагает интерпретацию, понимание и осмысление увиденного, в частности, в статусе безумия (оргии священного), предшествующего уму, уяснение его адаптационного (или эволюционного) смысла, от чего перекидывается мостик к трактовке самого смысла, очевидно усложняющего восприятие и в него инкорпорированного. Раздел сознания и воспринимаемого, структуры и механики инстанции, удерживающей предметность подвешенной на нитях абсурда (неоднозначности), и должны стать предметом анализа (очерчивающего синкретичные узлы активности, сочетающие не-проявленное ума, социума и безумия).

Интроспекции, застающие сознание в неестественности его само-открытости (очевидно, не предназначенного к самосознанию), проходят мимо причин противопоставления смысла его феноменам; переориентация на позитивную интерпретацию его и встраивание в эволюционную схему тем более актуальны. «Люди живут в мире смыслов, - пишет Адлер. - ...Ни один человек не может уйти от смыслов. Мы воспринимаем действительность всегда через призму смысла, который мы ей придаем» ${ }^{4}$. Сам Адлер трактует «смыслы»

4 Adler A. What life should mean to you. London: George Allen and Unwin, 1980. P. 14. 
через призму отнесения частных форм к более обширному контексту, охватывающему жизнь индивида. Психология в его лице обозначает себя ограниченностью интеллектуальной разметки; но если расширение кругозора и углубляет осмысленность, то механистическими ракурсами этот процесс очевидно не исчерпан. Даже предваряющий очерк придает смыслу типику, межеумочную по отношению к интеллекту (вдобавок процесс осмысления следовало бы более определенно пришвартовать к берегу систематики или абсурда или, наконец, определить пункт нейтральной прописки; этим отсутствием (нейтральной гавани) психология фундаментально перекрывает путь диагностике).

Между тем в этом пункте психология должна произвести первую сверку с философскими посылами; классическая философия, во всяком случае, полагает «адекватность» восприятия его непреходящим достоинством. Потратив века на расшифровку, она не подвергла сомнению эту очевидность. Вместе с тем подобная аксиоматика упускает необходимость сознания, его смысл и структуру генезиса, обусловленную, возможно, метаморфозом абсурда воображения в его квазиреалистических аспектах (не следует упускать из виду неразрешенность парадокса, в том числе в сфере восприятия известного как парадокс внутреннего гомункулуса; каким бы не был по пути в «мозг» подвергнут трансформациям исходный образ, он в конечном счёте должен всё же быть кемто воспринят; продуктивное разрешение предполагает за инстанцией восприятия-осознания ее специфическую активность, отличную от коммутаторного узла рефлекторного реагирования). Эта внутренняя активность осознания и должна быть дифференцирована с тем, чтобы разделиться на рефлексию осознанности и синкретизм спонтанности (смысла). В такой связи мысль Адлера, связующая многообразие коннотаций с вариативностью контекста, верна, но вместе с тем не закончена. В ней по-прежнему имплицитно заключена гипотетическая сила синтеза, пульсирующего от виртуальной «идеи» наступающего (целого) к частным фрагментам, обретающим определенность значений, и от их сложения - к утонченному целому (аналитика в структуре мышления утверждает аналогичные, но вялотекущие процессы анализа и синтеза, дифференциации и интеграции, индукции и дедукции). Но вариативность схемы бесконечного развертывания не может заполнить лакуны первичного приложения «идеи», в связи с чем этот акт покрывается мраком эстетического и мистикой интуитивного. Смысл в этом мраке обретает последнее убежище. Вместе с тем и «смысл», и «идея» не менее смутно связаны с субъектом сознания; они рассматриваются и в качестве рядовых инструментов мышления, но регулярно и «представляют» субъекта, «охваченного» идеей, «переживающего» некую проблему; интуиции, как принято считать, и рождаются в процессе подобного «вживания» (вместе с тем восточные школы направляют усилия на отрыв «самости» от (ей не тождественных) переживаний; они же особенно акцентируют разницу между широтой и глубиной знания, противопоставляя их). Но в уточнении состава и схематики познания (сознания) теряется вопрос о почве и причинах в его исходных коннотациях заключенного различия субъекта и объекта (в рамках классики такое различие считается естественным, и этот скрытый натурализм во многом дожил до настоящего времени).

Субъект и объект необходимо различны, и их различие в рамках пост-классической схемы не заключено в устройстве мироздания, выступая итогом длительного исторического пути, в основании которого расположены отношения индивидов, схемы их взаимного подчинения (в рабстве, в том числе семейном), сотрудничества и противодействия - и инвертирования таких форм, их преобразование в типические и индивидуальные схемы не-само-тождественности. И, следовательно, гносеология по крайней мере со времен публикации работ М. Фуко приобрела психологическое измерение. Схемы отстранения и остранения, преобразованные привычкой в условия осознания и осмысления, прежде имели некий специфический и прикладной смысл, и инициировались в ситуациях, в которых обычная рефлекторная реакция давала сбой - вместе с тем эта тайная гносеология (тайна гносеологии), проецируясь на внешний мир (социальные его структуры) встраивалась в системы существующих отношений и последние перестраивала, в том числе в утверждении харизматических иерархий, параллельности систем управления, их и в настоящее время непонятном дублировании, при котором светская суверенность отделена от секреций священного и сегрегирована в проекциях специфически-дольнего (в свой черед, под собой имеющих этажи обыденного и повседневного, далее - пораженного в правах). Человек с первых минут своего очеловечивания застает себя не 


\section{Философия и психология}

только в мире смыслов. Он обнаруживает вокруг дифференцированную социальную среду, в которой отсутствуют виды, но присутствуют «свои» (люди) и «чужие» (нелюди). Она вдобавок погружена в различные экзистенции, между которыми наличествует семантическая и отсутствует экзистенциальная коммуникация. Это «внутренние расы»: брахманы (в индуистской и ведической традициях), кшатрии, вайшья и шудры (не-люди). Экзистенциально-психологически варны влиты в социальную структуру, в которой онтология еще не обрела опор индивида и непосредственно реализована в структуре общности-коллектива. Между тем в этой примитивной структуре отсутствует индивидуальное сознание, и ее человечность непосредственно воплощена в отношениях каст, их специфической экзистенции. Она, возможно, и выступает следствием произвола, но не сознательного проекта, и порождает со временем среду, обуславливающую сознание. Но и прежде его продуцирования общность онтологически обусловлена структурой (нерефлекторной) активности и реципрокно служит для нее почвой (ориентируясь не столько на функции отражения (как частность), но на задачи «собирания» исходно-разрозненных экзистенций в единство общего смысла как смысла существования (жизни) общности).

По ту сторону натурализма не существует залогов того, что все подобные экзистенции от начала времен проникнуты единым сознанием, наделены единым смыслом существования и в один и тот же процесс мышления погружены. Аргументом в пользу такого утверждения служит общность языка; но по ту сторону априоризма следует признать семантические структуры так сложно устроенными не в целях «отражения мира», но в видах коммуникации экзистенции и ее продуктивного связывания (ни один тип экзистенции не безразличен к структуре познания; он, если конституирован осмыслением, неизбежно направлен на путь выявления метафизического единства (трансцендентности) данного; экспансия подразумевает представление предмета в его возможной активности, связанности ресурсами и слабостях схематизма; дольний интерес берет в оборот структуры обмена, условия внутреннего обращения ресурсов, предметные параметры и пр., что и обретает выражение в предметах теологии-метафизики, многообразных политиках, экономиках и пр.).

Уже эта схематическая экспозиция позволяет говорить о типологии смыслов экзистенции и на- мечать их онтологические различия - вместе с тем удерживая вопрос о смысле их связи, очевидно, не предшествующем общности, но вместе с нею возникшем и в ней непосредственно воплощенном:

- смысл конституируется в типологии четырех каст (чистая эмпирика); не вдаваясь в нее подробно, наметим «чистые» архетипы - экзистенции единого в интенции (наступающего), но в настоящем актуально разрозненного бытия, разрывающегося от тоски по «подлинной общности и полноте смысла»; это чистая трансцендентность «по ту сторону дольнего»; реалистическая трансцендентация экстатического презрения к смерти, стратагема экспансии/отражения, иначе, «путь воина» (бусидо); экзистенциал материального, «производства и обмена» в совокупности им обусловленных коннотаций; позиция «отверженных и оскорбленных» (тяготеющая к идеям первого рода экзистенций, и реализованная христианством).

- исключительность сакрального не только противопоставляет его специфику прочим, но уделяет ей центральную роль продуцирования смыслов (будущих идеологий); теологии как их ближайшие выразительницы, клерикальные системы, адаптирующие чистоту к дрязгам и иным маркерам имманентного, исторически обладают наибольшими ресурсами монополизма в сфере продвижения «смыслов», их адаптаций и компиляций;

- $\quad$ компиляция дважды рожденных отделяет экзистенции самоотверженности от «бытия-ксмерти» (Хайдеггером принятого за всеобщую его форму); это идеалы/идеологии аристократий в их отвержении смерти и различиях по отношении к открывающимся элитным позициям;

- $\quad$ первые три ступени отделяют «общность крови и почвы» от instrumentum vokale (по аналогии с архетипами Юнга; вместе с тем в рамках иной аналогии исключение исключений (шудры) рождает образ семантического пространства трех измерений: смысла, акта деструкции (силы/бессилия) и континуальной процессуальности).

Иными словами, исходные экзистенциальные архетипы обладают потенциалом схождения и отстранения, формируя не только касты и страты, но и политические союзы, идеологические течения и социально-экономические формации (нации и государства); в данном случае интерес представляет 
их внутреннее анатомирование, иначе, структура «установок», определяющих по преимуществу «точки зрения», или априористику смысла воспринимаемого.

Над этим конгломератом витает и гипотетическая общность смысла, в качестве проблемы заявившая о себе в пору глобализации и формируемая на почве (конкурирующих) идеологий (по ту сторону конъюнктуры представляющих в сердцевине проекты общественных структур, воплотивших общие смыслы бытия как смыслы (общественные идеалы) общностей). Это не касаясь обертонов, характеризующих игровые, эстетические, нравственные аспекты смысла; в их гипотетической всеобщности угадывается знакомая инерция классической философии. Но не первичны ли различия эстетики брахманов и вайшья, нравственности кшатриев и шудры по отношению к их единству (которое, лишенное метафизического натурализма, необходимо ведет происхождение от источника идеологии)? Не выступает ли в этой связи и «человек» проектом, но не реальностью бытия (за его равенство (братство в свободе и пр.) и ведут борьбу различные идеологии, скрывая внутри, как не раз подмечали наиболее бородатые, интересы тех или иных слоев (классов); но редукция корысти (каковая в рамках той же бородатости сформировала и религию, и многое иное) к ее онтологической необходимости возвращает к исходным типам экзистенции, рекрутирующим под знамена адептов). А между тем «человек» все еще населяет постклассическую философию. По ту ее сторону человек как непосредственно-общественное существо, видимо, предназначен к типологической фрагментации, обособленное существование детерминирующей в направлении общности в принципиальной дефрагментации самобытного (я; следственно, его реальная всеобщность очерчена ущербностью, вместе с чем его идеальное и обретает воплощение в (смутном) позыве; экзистенции также подпадают под онтологический зов дополнения до целого, в который частным случаем входит платоновский эрос; идеальные экзистенции Платона также достаточно близки к рассматриваемым; его Государство выступает слишком прямолинейной попыткой проецирования онтологической структуры в плоскость ряда сочетаний экзистенции).

Жертвуя классической фигурой человека, мы стремимся обменять ее на всеобщность той «общности», которая представлена минимизированной структурой отношений, и всеобщностью исходной типологии экзистенции. Возможно, этот минимализм чреват новой метафизичностью - но в такой связи мы вправе зарезервировать пространство структурности следующих уровней (родоплеменных союзов, государств и наций). Вместе с тем хотелось бы акцентировать связь и различие с первичными посылками структурологии: осмысленность исходной типологии берет начало в реальности окружения, условиях адаптации и на языке биологии выступает промером специфического симбиоза, в рамках которого вырожденные виды (экзистенции) дополняются до жизнеспособного родового целого в составе иерархического союза, в магическом кристалле которого их бытие становится мотивированным.

Препарирование психического не может минуть предварительную агрегацию осмысления. «Прежде чем понять самое душу, мы должны понять этот смысл (смысл понимания - Д.С.)» ${ }^{5}$. Внутреннее, в т.ч. бессознательное, суть то, в отношении чего внешнее (осознаваемое и воспринимаемое) обретает смысл. Но если он онтологически различен, обретая полноту вовне, то и внутреннее, включая и бессознательное, и подсознание, различаются по наполнению и по связи с инстанцией осознания (осмысления). Сакральное наполняется смыслом в ориентации на непосредственно-бессознательное (транс), в отличие от нацеленного на присутствие сознания, мотивированного представлением и процессом. И ложные взаимодействия самсары проступят в их соотношениях; последние встраиваются в ту безупречную иерархию, что обретает обличие (натуралистического) «монизма» (как идеала и идеи понимания).

Отличие от достоверного знания могло бы послужить краеугольным камнем трактовки смысла - в том случае, при котором подобное различие выйдет из натуралистических рамок и войдет в пространство онтологической психологии, полагающей знание, осмысление, веру и иные экзистенции в ряд сопряжено-общего и необходимо-ущербного бытия, со-временность которого выступает функцией продвижения к идеалу-соединимости.

Рекурсивность в условиях тотализации проектного бытия уже не служит почвой феномена или его симптомом. Вместе с тем диагностика деформаций единой схемы (психоаналитической структуры, самости, экзистенции) в такой связи тем бо5 Ясперс К. Общая психопатология. М.: Практика, 1997.
С. 337. 


\section{Философия и психология}

лее не оправдана. Отдельным и не менее значимым пунктом в этом ряду стоит интериоризация структурной общности, ее преломление в индивидуальной психике, дифференцированной в такой связи на экзистенции-смыслы рядов сакрального, пафосного, обыденного, отчужденного (вызывает сомнение в такой связи попытки навязывания «пребыванию» единой позиции в бытии (как и в случае с бытием-к-смерти); вряд ли «потерянность» и «брошенность» выступают общей чертой вот-бытия, но скорее элементом типологии отчуждения). Очерк онтологической психологии открывает профили вот-бытия, где «вот» связаны принципом дополнительности. Реконструкции начал за историческими рамками проекта (постмодерна), с учетом сказанного нацелены на раскрытие психического, в котором не сознание определяет структуру общности (наличного и процедур обобщения), но общность в необходимой структуре онтологического предопределяет индивида, истоки и характер его вот-бытия. Вместе с тем и дух, и тело, восходящие к исходным кодам культуры, предстают поздним продуктом природы человека вне культивируемых различий. В культе до-индивидуалистичный исход, в котором психология онтологически открыта психике, открывается в священной игре и священном безумии, сопричастность которым тождественна «полноценности» и, вместе с тем, мужественности-как-человечности. Этот примитивный сексизм также должен быть вставлен в ряд психологического генезиса онтологии.

Вместе с тем этот натурный снимок позволяет поставить вопрос об исходе психического, основанного общностью бытия. Другой (мана, сила или явление праотца, тотема), связываемый с индивидуальной структурой психического, должен обрести онтологический статус. У истоков истории утверждаются типы и структуры психического, в отнесенности к сакрально-пафосному (мужскому) и обыденному (женскому и подавленному). Это эпоха частичной человечности, не в отношении степени осознания, а в кардинальном делении на людейвоинов и подсобные силы (рабов и женщин).

\section{К вопросу о началах. Пред-сознательная осмысленность (энтузиазм) и промысел божий}

«Животное не является личностью, потому что оно не может встать над самим собой, противостоять самому себе. Поэтому для животного не существует и мир, противостоящий личности; для него существует лишь среда» ${ }^{6}$ «Для человека» существует и нечто иное, что он «себе» в состоянии противопоставить. Но подобно тому, как «Лишь отнесясь к человеку Павлу как к себе подобному, человек Петр начинает относиться к самому себе как к человеку» ${ }^{7}$ (К. Маркс), лишь противопоставляя себя Павлу, Петр противостоит себя сам (в статусе хозяина-Я). Общественные отношения задают параметры внутренней конституции; но тавтология не позволяет пролить свет на причины такой детерминации (внутреннего-внешним; животные включены в иерархии связей, например, антропоидные обезьяны пребывают в весьма структурированных по рангам стадах и семействах). Транспозиция внутреннего и внешнего не объясняет значимой в отношении человека инверсии, объяснение имитируя. Только человек наделен интенцией интериоризации, к ней внутренне предрасположен, обладая опытом отдачи себя, растворения в общем энтузиазме.

Человек противопоставляет себя миру, но не окружающей среде, во-вторых, не только в силу возможности «встать над собой»; в конечном счете, это чрезвычайно существенный, но и подсобный механизм решения некой задачи (реализации мотива), техника ее решения (и опора на «технику» и робинзонаду лишь следует господствующим мотивам западного мышления).

Человек противопоставляет себя миру, поскольку они (диалектически) едины в слушании «зова потустороннего», «служении высшему», и различны в их реализациях, в ограниченности материальных воплощений и процедур осознания (не затрагивая уже разумеющуюся буколику «зеленого мира»; мир предстает прежде всего иным человеческим мироустройством). Человек и мир подлинно едины по ту сторону данного, и лишь человек периодически оказывается на той стороне, дидактически утверждая поразившее его переживание.

И если «животное не является личностью, потому что не может встать над самим собой», то наиболее примитивной предпосылкой подобного пред-стояния выступает самоотречение, в (само) исступлении позволяющее проигнорировать «зов

6 Frankl V. Der Wille zum Sinn: Ausgewahlte Vortrage uber Logotherapie. 3., erw. Aufl. Bern: Huber, 1982. S. 116.

Маркс К. Капитал, т. I // Маркс К., Энгельс Ф. Собр. соч. М.: Государственное издательство политической литературы, 1954-1966. Т. 23. С. 338. 
плоти», подчиниться не себе (эго), но (общему) промыслу (дальний потомок которого представлен (общим) смыслом происходящего; в интеллектуальной осмысленности воплощены итоги окультуривания энтузиазма, инъекций в него традиций осознанности, автоматизм транспозиций смутных смыслов в общепонятные их выражения, образы, слова, жесты и знаки, автоматизм виртуальной игры преобразований идей в образы и слова и обратных преобразований образно-языковых композиций в смыслы, оставляя до времени в стороне содержание, стоящее за подобной механикой и обычно рассматриваемое в качестве преимущественного предмета психологии: отношения инстанции-я и субстанции, в их исторически переменчивых образах).

Потому экспликации общности со-бытия и психики нуждаются в пересмотре. Инстанция, в отношении которой реализуется подобная диспозиция, априори помещаясь в рамку сознания, в этом качестве фигурирует по бедности альтернатив. Скрытое означаюее характеризуется тут короткой связкой: «животное лишено сознания - оно не противопоставляет; человек сознанием наделен - он противопоставляет; следовательно, субъектом процесса выступает сознание». Но в отношении логики это заключение очевидно неверно. Сознание следует адресовать к тому же источнику, который обуславливает мотив противопоставления; последний также не обусловлен целью, но заключает смутные посылы целесообразности. Осмысление исхода осмысленности пред-сознания идет через предысторию психики, в коей «эго» пред-размечено генеральной интенцией обособленности, и в экстатическом трансе приносится в жертву субстанции. Здесь отсутствует механизм опосредования, здесь дух воюет с телом, размечая пространство души; в этом примитивном поле сталкиваются «два мира, две системы»: мир бессмертных, отрекшихся от «телесного плана бытия», оттолкнувших от себя короткое дыхание ужаса, «заступивших» за ограниченность частной позиции (в том числе в отношении порядка восприятий, фиксаций мест и времен), и мир «обреченных на смерть» и «заключенных в камеру тела», с его влечениями, их обслуживающими системами чувств и пр.

Обращение к артефактам с первых шагов открывает человеческую активность, в ритуале сознанию предшествующую. В тех же рамках феноменология явственно очерчивает фигуру, до и вне осознания характеризующую предмет обращения, антропологией и этнологией названный маной, духом, силой, тотемом. Ритуалы жертвоприношения и инициации (связанной со вторым рождением индивида или пере-рождением) направлены на ее вызов: «...слово, обозначающее ритуал... «жертвоприношение» (ср. лат. sacrificium, буквально «делание жертвы»/ сакрального/... еще очевиднее использование слова для жертвы в качестве обозначения ритуала вообще - др.-инд. Yajfla, нем. Opfer и др.)» ${ }^{8}$. Исступление, связываемое обычно со священным безумием, под каковым априори мыслится помрачение разума, полностью теряет почву при допущении отсутствия той почвы, с которой «сходят». Сложность обусловлена тем, что подобная аффектация не подпадает ни под известный инстинкт, но вне-сознательна. Если пытаться рассмотреть за подобным аффектом субстанцию действия, ее априори следует ввести в уловимый диапазон нерефлекторной бессознательной активности. Апофатическое описание искомого, т.о. уже готово, но, заполнить его пока нечем. Но: «Именно этот аффективный смысл обеспечивает синтез различных признаков, который оживляет их замерзшую наготу, придает им жизнь и какоето наполнение» ${ }^{9}$ (причем аффективный смысл действия Сартр вслед за Жане связывает с «отступлением сознания к магии»). Опуская аналогии узнавания, на ранее-известное опираемые ${ }^{10}$, следует подобный аффект адресовать беспрецедентному и под его воздействием инициируемой спонтанности. «Обеспечение синтеза различных признаков», в такой связи, обретает некую зыбкую почву; оно очерчивается ситуациями, в которых рефлекс не обеспечивает необходимых импульсов, не обретает внешнюю почву узнавания. Подобной пластичностью образа и не меньшей пластичностью «схем активности» наделен лишь человек, в отношении к себе подобным формирующий специфические приемы и средства опознания и реагирования, не опираемые на предварительные схематизации (под человеком имеется

\footnotetext{
8 Топоров В.Н. О ритуале. Введение в проблематику // Архаический ритуал в фольклорных и литературных памятниках. М., 1988. С. 24.

9 Sartre J.-P. The Psychology of Imagination. London: Methuen, 1972. XVIII. P. 31.

10 Дьюсбери Д. Поведение животных. Сравнительные аспекты. М.: Мир, 1981. С. 21.
} 


\section{Философия и психология}

в виду архаичный воин, внешний вид и приемы поведения которого подчинены не «человечности» в ее гипотетически-всеобем облике, но тотему с его духом и боевыми повадками; разумеется, и история спонтанных реакций, включая аффективные синтезы, не начинается с человека и более стара, нежели пресловутая история рефлексов; но а) именно человек ставит ее во главу своего выживания и, б) для биологии, игнорирующей роль активности восприятия, в ряде провокаций предмет раскрывающей, она представляет преимущественно белое пятно).

Пред-установка монопольного «узнавания», связующая его сверкой с ранее-бывшим, не только не позволила отличить осознанную реакцию от рефлекторной (исключив из осознания момент осмысления), но и познание рефлекса (инстинкта) подчинила тому же априори. Но если понимание «приспособления» худо-бедно может ограничиться подобными рамками, то данный пробел исключает понимание (реакции, поведения, логики эволюции) человека.

Упомянутая лакуна отчасти затемнена аналитикой сознания, восстановившего на почве языка и осмысленности ряд процедур узнавания (существенно их углубив и расширив). В этой связи тем более актуальна аналитика начал, в которых смысл («дух») прямо противопоставлен механике рефлекса (телу; в многообразии терминологического очерчивания значимы также и «одухотворение» как синоним экстатичности, и пафос как его содержательное предопределение и отсылка к исходному - оборонительному (вне-рефлекторному) «инстинкту»).

Феноменологическое очерчивание позволяет восстановить внешний абрис человечности в согласовании спонтанной активности. В этом исходе (ритуальной пред-настройке) обретается и трансцендентальная эстетика, и игровые ее аспекты; ориентация на беспрецедентное задает новое измерение согласованной настройке (инициированного настроения). Но в данном случае внешние условия (на протяжении тысячелетий придавшие первобытному кровавому культу как культурные формы, так и обрядовое наполнение) отступают на второй план, уступая место тем процессам, которые подчиняют и направляют само-исступленного (харизматика).

Исходные обстоятельства трансцендентного с точки зрения единства предстают кодами сонастроенностей, органично структурирующих активность разрозненной спонтанности. В такой связи следует вновь подчеркнуть ее внутреннюю конституцию: по ту сторону органики и гармонизации (трансцендентального эстетизма) это прежде всего активность, познающая нечто в ходе его (провоцирующего) раскрытия (ввязывающаяся в битву с готовностью раствориться в ее ходе возникающих «логиках» и «смыслах», инкорпорируемых в собственное переживание, открытое происходящему по ту сторону ужаса).

Удерживая прототип, имеющий источником сакрально-возвышенное, концентрируемое в психологической аббревиатуре «захваченности», увлечения-иным - как порога переключения в режим транса, самоотречения, следует продвигаться к очерчиванию его базальных модусов.

«Чистая трансцендентность», представшая началом человечности, полагает возможность прослеживания логики очеловечивания, связывающей забвение с ориентированием, в котором сознание чутко улавливает логику движения к цели и немедленно заключает в нее весь процесс (и, поскольку действие предстает симуляцией «первого действия», его воспроизводит, оно тем самым встраивается в механизм целеполагания готовым инструментом, модифицируемым по меркам контекста). Совокупность же культурных инструментов, вырывающих индивида из его локальности, эмоционально-художественные приемы подвешивания над обыденным наследуют в ослаблено-рефлексивной форме приемам исступленного транса: «Мы уверенно поступаем тогда, когда поступаем не от себя, а как одержимые имманентной необходимостью смысла той или другой культурной области» ${ }^{11}$. Вовлечение преодолевает порог осторожности, сразу отсекая индивида от пуповины знаково-символического представления мира (основанного как ни крути прецедентом и известным), ввергая в ад (восторг) непосредственного контакта, здесь и сейчас развертывающегося и требующего абсолютного растворения.

Пелена представления падает, уступая место невероятной живости соприкосновения, как соитие вне средств предохранения, необходимых и отдаляющих, сдернутая кожа, оголяющая нервы и вводящая постороннее во внутреннюю глубину.

11 Бахтин М.М. К философии поступка // Философия и социология науки и техники. Ежегодник 1984-1985. М.: Наука, 1986. C. 97. 


\section{Психология и психотехника 1(76) • 2015}

Онтологическая матрица обнаженного нерва поэта опирается на игру с неведомым, под которое временно подставляется собственная настроенность, «нерв» интонированной страстности.

Трудность понимания смысла вне сознания концентрируется вокруг не-алгоритмических реакций, которые им продуцировались. Феноменология Другого, закончив путь указаний, здесь уже далее именований (завладевающего самоотдающимся образа) продвинуться не в силах. В оставляемом сюжете стоит акцентировать диалектику пафоса-транса (трансцендентного): это, с одной стороны, оперативно-тактическое развертывание, обусловленное целями приспособления и нуждой (заботой), раскрываемое в спонтанной активности и ее эстетической связанности, или коллективной согласованности; но именно последняя, как черта психологии (эмоциональность), транспонирует индивида в иной горизонт бытия (экзистенции), обессмысливающий причины и практики заботы, и понуждающий к обретению «символов веры», ориентированных единением «бессмертных» в их обыденной (oxлажденной) ориентировке. Персонификация порыва дрожит и трепещет на грани безжалостного духа смерти и покойного духа безграничного единения по ту сторону бренного. Второй акцент может быть сделан на прагматически-модифицированные «следы» экстатического: эмоциональность (пред-настроенность), погруженная в пучину нужд и охлажденного восприятия, сохраняет схемы запредельной аффектации, подстраивая под них восприятие и переориентируя его на упомянутую «синтетичность».

\section{Смысл в себе и его персонификация в Другом}

Рассматривая интерпретацию Другого, данную Хайдеггером, следует заметить, что со-бытие с Другим необходимо связано с существом вот-бытия. «Со-бытие есть неотчуждаемое определение собственного существования» ${ }^{12}$.

Дальнейшее ознакомление проясняет его позицию. Событие лишено эксплицированной связи с бытием и связано с другими (забытье, растянутое на эпохи, повергает бытие бессилию и исключает из актуальной коммуникации; оно еще давало о себе знать в эпоху античности, но далее окончательно захирело).

12 Heidegger M. Sein und Zeit. Tübingen, 1986. S. 121.
Вместе с тем быть означает и быть самим собой; самобытность в такой связи и следовало бы эксплицировать в различии бытия (имманентно включающего общность) и вот-бытия, в его вотконфигурации реализующего смысл различия позиций (вот-) и их взаимное тяготение (те самые «призмы», которые ранее были размечены как экзистенциальные архетипы).

Пробел в этом пункте понуждает абсолютизировать момент внешнего различия; в модусе неподлинности я экзистирует как Другой. Другой назначается источником обезличивающих проектов моего существования. Другой Хайдеггера и Левинаса конституируется в пропуске его онтологического статуса, точнее, в негласной подмене его наличным. Неразбериха выдвигает на первый план (имплицитный) статус Другого как олицетворения власти, что скрывает массу неявных допущений, и прежде всего невозможность подлинной автономии (по крайней мере по отношению к трансляции культурных норм).

Такая постановка предопределяет параметры разрешения; позитивность Другого может быть реализована исключительно в статусе свободного сообщения (фактически низводящего к статусу другого, партнера-оппонента), и в Другом как субституте государственности заведомо порочна (за этими подстановками просматривается и идеологическая парадигма «демократии» в противопоставлении «тоталитаризму»).

Вместе с тем идеологические априори не в силах опрокинуть реалий, прорывающихся на онтологический горизонт необходимостью бытийного априоризма; феноменологически Другой (в статусе государственной системы образования, господствующих идеологий, законов и норм) предшествует «Я» и «Я» конституирует; «самореализация» Я не может далее пониматься иначе нежели «освобождение» от систем (нормирующих) предписаний; подобное «освобождение» не наполняет «свободу» позитивным содержанием, но элиминирует онтологию Другого в просвете демократических свобод (индивида) и свободных проектов (временных коллективов), выводя в наличное гипостазируемые и предвзятые статуты правового общества.

Реконструкция Другого в горизонте онтологии предполагает как уяснение необходимости субстанции (в противовес инстанции-Я), так и причин противопоставления ее идеологии. Или тотальная властность Другого обосновывается 


\section{Философия и психология}

априорным вменением ему функций власти, или причинами устроения человеческого бытия, при которых идеология олицетворяется Другим; объяснения, ставящую алчность (элит) управлять государством (бытия), вряд ли стоит серьезно рассматривать.

Психологи в трактовке смыслов также не торопятся выходить из границ индивида, и тем не менее, понуждаемы к этому существом дела: «Смысл жизни нельзя вывести из каузальных отношений, и тем более из личных воображаемых представлений, а лишь... из преследования цели, из поиска решения задачи, заданного через ее условия» - утверждает Адлер ${ }^{13}$. Адлер связывал смысл (жизни) с «неличными представлениями», подлинными целями, которые и привносят в (конъюнктурное) существование осмысленность. Схоже модифицировано целое Юнга: «Поэтому я предложил называть самостью ... наличную, но не полностью постижимую целокупную личность. Согласно такому пониманию «я» подчинено самости и относится к ней, как часть к целому» ${ }^{14}$. В гипотетически целом-(самости), в свой черед, выделяются «личностное» и «коллективное». «Содержания личностного бессознательного суть завоевания индивидуальной жизни, содержания же коллективного бессознательного - всегда и априорно наличные архетипы» ${ }^{15}$. Юнг (неосознанно) стремиться нагрузить самость алгоритмами (или архетипами), в знании усматривая опору активности; алгоритм априори признан предметом поиска; объясняя его скрытность, его следует спрятать в подсознании, вместе с тем объясняя и сложный механизм его воздействия на сознание (но не объясняя его «синтетическую функцию» и «целостность»).

Проблема в том, что традиционная культура (традиционное общество как гипотетическое ее выражение) не нуждается в укрытии собственных основ; они, напротив, манифестируются ритуалами, обрядами, культами, мифами и иными формами культуры. Следует познавать не то, что укрыто культовыми манифестациями, но то, напротив, что ими навязывается, ради чего они возникли и что будируют (пусть это будут архетипы, но архетипы осмысленной реакции, но не стереотипного отношения, архетипы сопричастности общей тайне, но не тайные приемы соучастия, архетипы субъекта, обладающего внутренней связностью настроек при их внешне-разрозненной, непредсказуемой реализации, но не архетипы механизма, извечно повторяющего себя и связанного регламентом).

А актуализируют они известное открытие духа (Духу), в котором индивид открывается силе и ею направляется (не входя в тонкости становящихся идеологий (религий), монополизирующих коммуникацию с вышним и принимающих функции его представительства). Бессознательное в рамках подобных сопоставлений должно обрести почву не в скрытых архетипах, но в явных и нескрываемых манифестациях горнего - предназначенных к выразительности. Вытесненное же должно обрести понимание в рамках процесса подавления сознанием подобного процесса, его вытеснения в подвалы пред-сознательного и эмоционально-предчувствуемого.

Возвращаясь в такой связи к началу и вместе с тем подводя итоги, следует утвердить «вытесненное подсознательное» (экзистенциальные архетипы) в совершенно иных в сравнении с принятыми сферах.

Назовем четыре базальных архетипа, «вытесняемых» в сферу бессознательного не в силу их чужеродности сознанию, но в силу их онтологической роли в составе психического, ранее упомянутой роли «призм», предсознательных установок, привносящих в миро-окружность «смысл», не сводимый к наличным формам и априори выступающий субъектом их внятности (в этом минимализме мы, разумеется, отвлекаемся от массы деталей, отчасти обозначенных ранее в тексте):

- архетип Всевышнего, Бога-Отца, Абсолюта, Единого и пр.;

- $\quad$ архетип Власти;

- $\quad$ архетип Капитала;

- $\quad$ архетип Сервера.

13 Adler A. Psychotherapie und Erziehung: Ausgewahlte Aufsatze. Bd I: 1919-1929 / Hg. von H.L. Ansbacher, R.F. Antoch. Frankfurt am Main: Fischer Taschenbuch Verlag. 1982 a. S. 8283.

14 Юнг К.Г. Эон. Исследование о символике самости. М.: Академический проект, 2009. С. 14.

15 Там же. С. 17. 


\section{Психология и психотехника 1(76) • 2015}

\section{Список литературы:}

1. Бахтин М.М. К философии поступка // Философия и социология науки и техники. Ежегодник 1984-1985. М.: Наука, 1986. С. $80-160$.

2. Гуссерль Э. Идеи к чистой феноменологии и феноменологической философии (1913). М.: Лабиринт, 1994.110 с.

3. Дьюсбери Д. Поведение животных. Сравнительные аспекты. М.: Мир, 1981.

4. Маркс К. Капитал, т. I // Маркс К., Энгельс Ф. Собр. соч. М.: Государственное издательство политической литературы, 1954-1966. Т. 23.

5. Спектор Д.М. Власть времени. М. Социальный проект, 2009. 560 с.

6. Топоров В.Н. О ритуале. Введение в проблематику // Архаический ритуал в фольклорных и литературных памятниках. М., 1988. 332 с.

7. Хайдеггер М. Время и бытие: статьи и выступления. М.: Республика, 1993. 447 с.

8. Юнг К.Г. Эон. Исследование о символике самости. М.: Академический проект, 2009. 340 с.

9. Ясперс К. Общая психопатология. М.: Практика, 1997. 1053 с.

10. Adler A. What life should mean to you. London: George Allen and Unwin, 1980. 300 p.

11. Adler A. Psychotherapie und Erziehung: Ausgewahlte Aufsatze. Bd I: 1919-1929 / Hg. von H.L. Ansbacher, R.F. Antoch. Frankfurt am Main: Fischer Taschenbuch Verlag. 1982 a. 267 s.

12. Sartre J.-P. The Psychology of Imagination. London: Methuen, 1972. XVIII, $234 \mathrm{p}$.

13. Frankl V. Der Wille zum Sinn: Ausgewahlte Vortrage uber Logotherapie. 3., erw. Aufl. Bern: Huber, 1982.344 s.

14. Heidegger M. Sein und Zeit. Tübingen, 1986.

\section{References (transliteration):}

1. Bakhtin M.M. K filosofii postupka // Filosofiya i sotsiologiya nauki i tekhniki. Ezhegodnik 1984-1985. M.: Nauka, 1986. S. 80160.

2. Gusserl' E. Idei k chistoi fenomenologii i fenomenologicheskoi filosofii (1913). M.: Labirint, $1994.110 \mathrm{~s}$.

3. D’yusberi D. Povedenie zhivotnykh. Sravnitel'nye aspekty. M.: Mir, 1981.

4. Marks K. Kapital, t. I // Marks K., Engel's F. Sobr. soch. M.: Gosudarstvennoe izdatel'stvo politicheskoi literatury, 1954-1966. T. 23.

5. Spektor D.M. Vlast' vremeni. M. Sotsial'nyi proekt, 2009. $560 \mathrm{~s}$.

6. Toporov V.N. O rituale. Vvedenie v problematiku // Arkhaicheskii ritual v fol'klornykh i literaturnykh pamyatnikakh. M., 1988. $332 \mathrm{s.}$

7. $\quad$ Khaidegger M. Vremya i bytie: stat'i i vystupleniya. M.: Respublika, 1993. $447 \mathrm{~s}$.

8. Yung K.G. Eon. Issledovanie o simvolike samosti. M.: Akademicheskii proekt, 2009. $340 \mathrm{~s}$.

9. Yaspers K. Obshchaya psikhopatologiya. M.: Praktika, 1997. 1053 s.

10. Adler A. What life should mean to you. London: George Allen and Unwin, 1980. 300 p.

11. Adler A. Psychotherapie und Erziehung: Ausgewahlte Aufsatze. Bd I: 1919-1929 / Hg. von H.L. Ansbacher, R.F. Antoch. Frankfurt am Main: Fischer Taschenbuch Verlag. 1982 a. 267 s.

12. Sartre J.-P. The Psychology of Imagination. London: Methuen, 1972. XVIII, $234 \mathrm{p}$.

13. Frankl V. Der Wille zum Sinn: Ausgewahlte Vortrage uber Logotherapie. 3., erw. Aufl. Bern: Huber, 1982.344 s.

14. Heidegger M. Sein und Zeit. Tübingen, 1986. 